\title{
Shan Language
}

National Cancer Institute

\section{Source}

National Cancer Institute. Shan Language. NCI Thesaurus. Code C154114.

A Kra-Dai language that is spoken by the Shan people, mostly in the Shan State of Myanmar. 